\title{
Optimalisasi Penegakan Hukum Pidana Terhadap Tindak Pidana Perikanan (Studi Perbandingan Hukum Pidana Di Bidang Perikanan)
}

\author{
Astuti Nur Fadillah ${ }^{1 *}$, Muhammad Insan Anshari Al Aspary ${ }^{2}$ \\ ${ }^{1}$ Fakultas Hukum Universitas Pattimura, Ambon, Indonesia \\ ${ }^{2}$ Kejaksaan Republik Indonesia. Jakarta, Indonesia \\ *E-mail: astutifadillah@gmail.com
}

\begin{tabular}{l}
\hline Info Artikel \\
\hline \\
Keywords: \\
Fisheries Crime; \\
Criminal Law \\
Enforcement; \\
Criminal Liability. \\
\\
Pridana. \\
Pertanggungjawaban \\
Pindak Pidana \\
Perikanan; \\
Pidana; \\
Pian Hukum \\
Panci: \\
Pana
\end{tabular}

Abstract
For the fisheries sector in Indonesia, Law No. 31 of 2004 Jo. Law
No. 45 of 2009 concerning Fisheries and in the Philippines the 1998
Philippine Fisheries Code applies, which is a regulation governing
prison administration. Indonesian fisheries law has not yet enacted
a ban on rare and endangered species. The Philippine fisheries law
does not yet impose legal sanctions to cancel permit documents. The
formulation of an emergency prison sentence or a Philippine
fisheries law fine is relatively heavier than Indonesia. For the
concept of accountability of the court by the two countries still
imposes court responsibility only on corporate management. Law
enforcement in the field of fisheries in Indonesia and the Philippines
can be more effective on the prohibition of certain activities or
activities related to liability related to relationships that can be
accounted for, so that they can be accounted for in the right way, to
help and overcome problems related to fisheries.
Abstrak
Untuk sektor perikanan di Indonesia berlaku Undang-Undang No. 31
Tahun 2004 Jo. Undang-Undang No. 45 Tahun 2009 Tentang
Perikanan dan di Filipina berlaku The Philippine Fisheries Code of
1998 yang merupakan perundang-undangan administratif bersanksi
pidana. Undang-undang perikanan Indonesia belum mengatur
tentang larangan menangkap spesies yang langka dan terancam
punah. Undang-undang perikanan Filipina belum memiliki sanksi
pidana bagi pelanggaran pemalsuan surat-surat perizinan. Perumusan
ancaman pidana penjara ataupun denda undang-undang perikanan
Filipina relatif lebih berat dibandingkan Indonesia. Untuk konsep
pertanggungjawaban pidana korporasi oleh kedua negara masih
membebankan pertanggungjawaban pidana hanya kepada pengurus
korporasi. Penegakan hukum pidana bidang perikanan di Indonesia
dan Filipina dapat lebih efektif apabila diadakan pelarangan terhadap
aktivitas atau perbuatan tertentu dan penggunaan ajaran
pertanggungjawaban mutlak serta pengaturan korporasi sebagai
pelaku sehingga mampu dipertanggungjawabkan secara pidana
merupakan solusi yang tepat bagi kedua negara untuk mencegah dan
menanggulangi tindak pidana perikanan.




\section{A. PENDAHULUAN}

Perikanan merupakan suatu kegiatan yang berhubungan dengan pengelolaan dan pemanfaatan sumber daya ikan dan lingkungannya mulai dari praproduksi, produksi, pengolahan sampai dengan pemasaran, yang dilaksanakan dalam suatu bisnis perikanan. ${ }^{1}$ Oleh karena perikanan merupakan suatu bagian kegiatan bisnis, hal tersebut mengisyaratkan pula bahwa fenomena usaha pemanfaatan sumber daya ikan akan berkembang dengan sangat pesat, apalagi komoditi yang dihasilkan memiliki prospek yang cukup baik. Dalam kaitan ini, perikanan telah menjadi komoditi penting bagi masyarakat dunia. ${ }^{2}$ Permintaan produk-produk dari sektor perikanan juga meningkat dua kali lipat selama 30 tahun terakhir dan diperkirakan akan terus meningkat dengan ratarata $1,5 \%$ pertahun sampai tahun 2020 yang akan datang.

Indonesia sebagai negara yang memiliki garis pantai terpanjang kedua di dunia tentu juga mempunyai keuntungan. Keuntungannya adalah Indonesia memiliki potensi yang dapat digali terutama sumber daya alam (SDA) yang terkandung dalam lautan teritorialnya. Sumber daya alam yang terdapat dalam kandungan laut Indonesia sangatlah beragam dan mempunyai nilai ekonomi yang tinggi. Sumber daya alam itu termasuk migas (minyak dan gas) dan tentunya segala macam jenis ikan.

Indonesia adalah salah satu pengekspor sumber daya alam sektor perikanan yang terbesar di dunia. Hampir sebagian besar juga sektor perikanan turut menyumbangkan pendapatan negara melalui anggaran pendapatan belanja negara (APBN) dan sumber penghasilan potensial bagi daerah melalui anggaran pendapatan belanja daerah (APBD). Selain itu, sektor perikanan mampu untuk menyediakan lapangan pekerjaan bagi hampir sebagian besar masyarakat Indonesia.

Filipina sama halnya Indonesia yang terletak pada kawasan Asia Tenggara juga memprioritaskan field perikanan sebagai barometer utama perekonomian negara. Filipina melalui Kementerian Perikanan dan Kelautan telah memaksimalkan pendapatan negara melalui sektor perikanan sampai pada kurun waktu tahun 2018-2019 yang lalu. Produk kebijakan dikeluarkan untuk mewujudkan tujuan tersebut yang tentu saja berkonsentrasi pada ketentuan-ketentuan formal bidang perikanan, khususnya mengenai izin perikanan dan membuka pemodal-pemodal besar (utamanya investor asing) untuk menanamkan investasi di Filipina. Sekedar informasi bahwa perencanaan produk perikanan Filipina telah mencapai 990.14 metrik ton. ${ }^{3}$ Selain itu, Filipina merupakan negara yang berusaha untuk meraih kualitas nilai ekspor perikanan ke berbegai negara, khususnya Uni Eropa.

Permintaan produksi biota laut yang terus melonjak tinggi sebagai bagian dari respon pasar internasional tentunya memiliki makna positif bagi pengembangan perikanan, terlebih bagi negara kepulauan seperti Indonesia dan Filipina yang memiliki potensi perikanan (baik laut maupun darat) yang cukup luas dan potensial untuk mengembangkan teknologi baik penangkapan maupun akuakultur serta meningkatkan taraf hidup para nelayan. Namun, tuntutan pemenuhan kebutuhan akan sumber daya perikanan pasti diikuti oleh tekanan eksploitasi ikan yang juga semakin intensif dan berlebihan. Apabila tanpa disertai manajemen yang professional dan bijaksana, sangat dikhawatirkan pemanfaatan sumber daya perikanan secara berlebihan otomatis membawa usaha perikanan ke gerbang kerusakan dan terjadinya berbagai konflik terhadap

1 Republik Indonesia, Undang-Undang Tentang Perikanan, UU Nomor 31 Tahun 2004, TLN Nomor 4433.

2 Fauzi, A. (2005) Kebijakan Perikanan dan Kelautan. Jakarta: Gramedia Pustaka Utama., h. 11.

3 https://psa.gov.ph/fisheries-situationer. (Diakses pada tanggal 3 Mei 2019). 
pengelolaan sumber daya perikanan. ${ }^{4}$

Informasi sisi kajian ilmu perikanan diperoleh kalau para ilmuwan mengkhawatirkan bahwa pada tahun 2048, seluruh usaha sektor perikanan akan lumpuh total jika tidak dilakukan perubahan yang mendasar dalam pengelolaan potensi kelautan dan perikanan dunia. Sejak 1900-an hingga kini, banyak jenis ikan populasinya telah menurun drastis hingga tersisa hanya sebesar $10 \%$ saja, dampaknya akan sangat terasa bagi negara-negara yang sangat bergantung dengan sumber daya perikanan sehingga akan mengalami krisis sosial, ekonomi dan lingkungan yang parah. ${ }^{5}$

Kegelisahan para ilmuwan dipicu pula oleh perilaku-perilaku non-coperative baik ruanglingkup nasional maupun internasional akhir-akhir ini yang makin sering terjadi di bidang perikanan, baik perikanan sektor laut maupun darat. Penggunaan bahan peledak, kimia, biologi, pencurian ikan, dan penggunaan alat tangkap tidak sesuai prosedur adalah contoh dari bentuk tindakan "non-coperative" dari pelaku usaha di bidang perikanan. Berdasarkan hasil kajian dari aspek ilmu kriminologi, pelanggaran di bidang perikanan ini sarat bermotifkan faktor ekonomi. ${ }^{6}$

Tindak pidana perikanan merupakan genus dari aktivitas-aktivitas illegal yang terjadi dalam pengelolaan perikanan. Tindak pidana perikanan juga melampaui batasbatas wilayah negara baik mengenai tempat terjadinya, akibat-akibat yang ditimbulkannya maupun tujuannya. ${ }^{7}$ Tindak pidana perikanan merupakan dampak negatif yang muncul sebagai konsekuensi untuk memperoleh sumber daya perikanan semaksimal mungkin. Tindak pidana perikanan meliputi semua pelaku yang terlibat dalam sektor perikanan, seperti,: nelayan, pemilik kapal, nahkoda, pengusaha pelelangan, orang asing, aparatur pemerintah, dan lain-lain sebagainya. Tindak pidana perikanan dapat ditekan kuantitas maupun kualitasnya dengan memaksimalkan upaya penegakan hukum, khususnya hukum pidana.

Penegakan hukum pidana bidang perikanan meliputi aspek formil maupun materill. Penegakan hukum pidana dalam aspek formil meliputi aturan-aturan prosedur (penyelidikan, penyidikan, dan pemeriksaan pengadilan) bagi aparat penegak hukum ketika menangani tindak pidana perikanan. Penegakan hukum pidana materill berupa pelarangan berbagai aktivitas-aktivitas tertentu atau berpotensi berbahaya dalam dunia perikanan menjadi bentuk perundang-undangan yang disertai sanksi pidana. Untuk mengkhususkan permasalahan, tulisan ini berfokus terhadap aspek hukum pidana materill saja.

Perbandingan hukum pidana bidang perikanan Indonesia dan Filipina bagi pengetahuan bidang hukum pidana sangat menarik untuk diketahui. Indonesia dan Filipina pasti memiliki perundang-undangan perikanan untuk mencegah dan menanggulangi segala macam bentuk tindak pidana perikanan. Perbandingan hukum pidana materill bidang perikanan dalam tulisan ini meliputi: perbuatan-perbuatan yang dilarang, sanksi pidana, dan pertanggungjawaban pidana (individu/korporasi) dimana Indonesia dan Filipina kemungkinan memiliki persamaan maupun perbedaan. Persamaan

${ }^{4}$ Widodo, J dan Suadi. (2006). Pengelolaan Sumber Daya Perikanan Laut. Yogyakarta: Gajah Mada University Press., h. 1-2.

5 http://www.pulauseribu.co/2011/10/krisis-perikanan-dunia.html. (Diakses pada tanggal 3 Mei 2019).

6 Bouman, P. J. (1961). Sosiologi Pengertian Dan Masalah. Semarang: Yayasan Kanisius, h. 101.

7 Parthiana, I W. (2003). Hukum Pidana Internasional Dan Ekstradisi. Bandung : Yrama Widya., h. 41. Lihat pula dalam Pakes, F. (2010). Comparative Criminal Justice. Cullompton : Willan Publishing., h. 3. 
dan perbedaan antara Indonesia dan Filipina diharapkan mampu memberikan solusi bagi kedua negara, terutama Indonesia dalam mencegah dan menanggulangi tindak pidana bidang perikanan.

Filipina dipilih sebagai negara pembanding karena negara itu mengandalkan sektor perikanan sebagai sumber utama pendapatan negara. Selain itu, Filipina merupakan negara dengan penegakan hukum pidana yang tergolong baik diantara negara-negara ASEAN lainnya. Untuk itu, perbandingan hukum ini secara tidak langsung dapat memberikan support penegakan hukum pidana bidang perikanan di Indonesia agar menjadi lebih berkualitas dan efektif, begitupun halnya Filipina.

Berdasarkan uraian pendahuluan diatas, maka penulis diambil sejumlah permasalahan, yaitu Bagaimanakah pengaturan tindak pidana, sanksi pidana dan pertanggungjawaban pidana bidang perikanan di Indonesia, bagaimanakah pengaturan tindak pidana, sanksi pidana dan pertanggungjawaban pidana bidang perikanan di Filipina. Berdasarkan perbandingan hukum Indonesia dan Filipina, bagaimanakah langkah-langkah yang sebaiknya diambil oleh kedua negara agar mampu untuk mencegah dan menanggulangi tindak pidana perikanan secara efektif dan maksimal.

\section{B. METODE PENELITIAN}

Penggunaan metode penelitian tulisan ini adalah menggunakan metode penelitian normatif. Suatu metode dimana hukum dikonsepkan sebagai apa yang tertulis dalam peraturan perundang-undangan atau hukum dikonsepkan sebagai kaidah atau norma yang merupakan patokan berperilaku manusia yang dianggap pantas. ${ }^{8}$ Data yang dipergunakan adalah data sekunder dengan prioritas pengumpulan bahan hukum primer (undang-undang perikanan Indonesia-Filipina), bahan hukum sekunder dan bahan hukum tersier. ${ }^{9}$ Data yang peroleh kemudian diolah dan disajikan secara analisisdeskriptif.

\section{PEMBAHASAN}

\section{Pengaturan Tindak Pidana Perikanan Di Indonesia}

\section{a. Bentuk Tindak Pidana}

Sistem hukum Indonesia adalah civil law sistem yang pada awalnya dibawa oleh Kolonial Belanda, sebelum dan sesudah perang Dunia II. Dalam civil law sistem atau sistem hukum eropa daratan, kodifikasi merupakan sumber hukum utama. ${ }^{10}$ Kodifikasi adalah kumpulan klausa umum yang otoritatif, komprehensif, sistematik, dan beberapa prinsip hukum, terbagi dalam beberapa buku atau bagian yang dimana saling terkait dan berhubungan. ${ }^{11}$ Oleh karena itu, kodifikasi ini sarat dengan upaya untuk menghimpun materi hukum tertentu atau spesifik baik itu hukum perdata,

8 Amiruddin \& Asikin, H. Z. (2008). Pengantar Metode Penelitian Hukum. Jakarta : Rajawali Pers., h. 118 .

9 Soekanto, S. (1986). Pengantar Penelitian Hukum. Jakarta : UI-Press., h. 51.

10 Surachman, R. M, \& Maringka, J. S. (2015). Peran Jaksa Dalam Sistem Peradilan Pidana Di Kawasan Asia Pasifik. Jakarta : Sinar Grafika., h. 6. Lihat pula dalam Surachman, R. M. Dkk. (2015) Eksistensi Kejaksaan Dalam Konstitusi Di berbagai Negara. Jakarta : Sinar Grafika., h. 30.

11 Cruz, P. D. (1993). A Modern Approach to Comparative Law. Boston : Kluwer. dalam Santoso, T. (2007). Perbandingan Hukum Pidana, Depok: Program Pascasarjana Universitas Indonesia. 
hukum pidana, hukum dagang dan hukum acara perdata. ${ }^{12}$ Namun seiring perkembangan hukum, dogma bahwa kodifikasi merupakan satu-satunya sumber hukum sudah tidak dipegang teguh lagi, banyak negara dengan civil law sistem juga menganut bahwa putusan hakim sebagai sumber hukum yang penting.

Untuk mengendalikan dan meminimalisir perilaku-perilaku menyimpang dalam bidang perikanan diberlakukanlah Undang-Undang No. 31 Tahun 2004 jo. UndangUndang No. 45 Tahun 2009 Tentang Perikanan. Untuk penegakan hukum pidana bidang perikanan di Indonesia diatur dalam BAB XV Ketentuan Pidana UndangUndang No. 31 Tahun 2004 jo. Undang-Undang No. 45 Tahun 2009 Tentang Perikanan. Terdapat 17 (tujuh belas) macam bentuk aktivitas bidang perikanan yang dapat dikenakan sanksi pidana. 17 (tujuhbelas) macam bentuk aktivitas tersebut dapat dibagi dalam 4 (empat) golongan tindak pidana sebagaimana disajikan dalam tabel dibawah ini :

Tabel 1.

Golongan Tindak Pidana Perikanan Di Indonesia

\begin{tabular}{|c|c|}
\hline Golongan Tindak Pidana & Pasal \\
\hline $\begin{array}{lll}\begin{array}{l}\text { Perusakan sumber daya } \\
\text { perikanan }\end{array} & \\
\end{array}$ & $\begin{array}{l}\text { 1) penggunaan bahan kimia atau } \\
\text { semacamnya (Pasal 84), } \\
\text { 2) pembudidayaan spesies ikan tertentu } \\
\text { yang membahayakan sumber daya } \\
\text { perikanan (Pasal 88) } \\
\text { 3) penggunaan bahan baku yang } \\
\text { berbahaya (Pasal 91). }\end{array}$ \\
\hline Pelanggaran perizinan & $\begin{array}{l}\text { 1) usaha perikanan tanpa kepemilikan } \\
\text { SIUP (Pasal 92); } \\
\text { 2) pengoperasian kapal penangkapan ikan } \\
\text { tanpa kepemilikan SIPI di laut lepas } \\
\text { atau ZEEI (Pasal 93 ayat 1, 2, 3, dan4); } \\
\text { 3) pemalsuan SIUP, SIPI, dan SIKPI } \\
\text { (Pasal 94A) } \\
\text { 4) pengoperasian kapal asing tanpa izin } \\
\text { (Pasal 97 ayat 1, 2 dan3); } \\
\text { 5) nahkoda yang tidak memperoleh izin } \\
\text { berlayar (Pasal 98); } \\
\text { 6) penelitian perikanan tanpa izin (Pasal } \\
\text { 99); } \\
\text { 7) Pemalsuan SIUP, SIPI, dan SIKPI oleh } \\
\text { pejabat yang terkait (Pasal 100A). }\end{array}$ \\
\hline Penangkapan ikan illegal & $\begin{array}{l}\text { a. Penggunaan alat/metode Penangkapan } \\
\text { ikan yang tidak sesuai ukuran atau } \\
\text { standar yang telah ditetapkan (Pasal 85) } \\
\text { Membangun, mengimpor, atau } \\
\text { memodifikasi kapal perikanan yang } \\
\text { tidak mendapat persetujuan (Pasal 95), } \\
\text { b. Tidak mendaftarkan kapal perikanan } \\
\text { (Pasal 96). }\end{array}$ \\
\hline
\end{tabular}

12 Syaukani, I \& Thohari, A. (2004). Dasar-Dasar Politik Hukum, Jakarta : Rajawali Pers., h. 124. 


\begin{tabular}{|l|l|l|}
\hline $\begin{array}{l}\text { Pelanggaran produksi dan } \\
\text { pemasaran sumber daya } \\
\text { perikanan. }\end{array}$ & a. $\begin{array}{l}\text { Tidak memenuhi persyaratan kelayakan } \\
\text { pengelolaan ikan, sistem jaminan mutu, } \\
\text { dan keamanan hasil perikanan (Pasal } \\
\text { 89). } \\
\text { b. Pemasukan atau pengeluaran hasil } \\
\text { perikanan tanpa dilengkapi pula dengan } \\
\text { sertifikat kesehatan layak konsumsi } \\
\text { bagi manusia wajib pula terpenuhi } \\
\text { (Pasal 90). }\end{array}$ \\
\hline $\begin{array}{l}\text { Pelanggaran yang dilakukan } \\
\text { oleh nelayan kecil. }\end{array}$ & a. $\begin{array}{l}\text { Pelanggaran larangan-larangan } \\
\text { sebagaimana diatur dalam UU } \\
\text { Perikanan (Pasal 100B). } \\
\text { Pelanggaran terhadap Pasal 7 ayat }(2)^{13} \\
\text { (Pasal 100C). }\end{array}$ \\
\hline
\end{tabular}

Berdasarkan penggolongan diatas bahwa terdapat perbuatan atau aktivitas tertentu dibidang perikanan dapat dibebankan pidana. Penggunaan bahan kimia dan pelanggaran perizinan menjadi perbuatan yang dapat dikenakan sanksi pidana. Pelanggaran-pelanggaran lainnya seperti : penangkapan illegal, pelanggaran ketentuan produksi dan pemasaran sumber daya perikanan dikategorikan pula sebagai tindak pidana. Ketentuan mengenai tindak pidana yang dilakukan oleh nelayan kecil/pembudidaya ikan kecil diatur pula dalam ketentuan UU Perikanan Indonesia.

\section{b. Sanksi Pidana}

Sanksi pidana dalam Undang-Undang No. 31 Tahun 2004 jo. Undang-Undang 45 Tahun 2009 Tentang perikanan terdiri atas 2 jenis, yaitu pidana penjara dan denda. Pidana penjara bervariasi antara 1 (satu) tahun sampai 7 (tujuh) tahun, begitupun dengan pidana denda bervariasi antara Rp. 100.000.000,00 (seratus juta rupiah) sampai Rp. 20.000.000.000.00 (dua puluh milliar rupiah). Perumusan sanksi pidana menurut Undang-undang perikanan Indonesia adalah sebagian besar kumulatif. Khusus untuk nelayan kecil/pembudidaya ikan kecil perumusan sanksi pidana berbentuk alternatif dan tunggal.

\section{c. Pertanggungjawaban Pidana}

Pertanggungjawaban pidana pelaku (individu) tindak pidana perikanan masih dianut oleh Undang-Undang No. 31 Tahun 2004 jo. Undang-Undang No. 45 Tahun 2009 tentang Perikanan. Unsur-unsur pertanggungjawaban pidana dalam hal kesalahan berbentuk kesengajaan, kelalaian atau sikap batin masih terdapat dalam jumlah keseluruhan rumusan tindak pidana, seperti penggunaan bahan kimia/peledak dan masih harus dibuktikan oleh penuntut umum dalam persidangan.

13 Jenis, jumlah, ukuran alat penangkapan ikan; Jenis, jumlah, ukuran, dan penempatan alat bantu penangkapan ikan; Daerah, jalur, dan waktu atau musim penangkapan ikan; Sistem pemantauan kapal perikanan; Jenis ikan baru yang dibudidayakan; Jenis ikan dan wilayah penebaran kembali serta penangkapan ikan berbasis budidaya;Pembudidayaan ikan dan perlindungannya; Pencegahan pencemaran dan kerusakan sumber daya ikan serta lingkungannya; Ukuran atau berat minimum jenis ikan yang boleh ditangkap; Suaka perikanan; Wabah dan wilayah wabah penyakit ikan; Jenis ikan yang dilarang untuk diperdagangkan, dimasukkan. Dan dikeluarkan ke dan dari wilayah Republik Indonesia; dan Jenis ikan yang dilindungi. 
Untuk korporasi atau badan hukum, ketentuan Undang-Undang No. 31 Tahun 2004 jo. Undang-Undang No. 45 Tahun 2009 juga mengakomodasi tentang pertanggungjawaban pidana bagi korporasi. Ketentuan ini sebagaimana diatur dalam Pasal 101 yang berbunyi :

"Dalam hal tindak pidana sebagaimana dimaksud dalam pasal 84 ayat (1), Pasal 85, Pasal 86, Pasal 87, Pasal 88, Pasal 89, Pasal 90, Pasal 91, Pasal 92, Pasal 93, Pasal 94, Pasal 95, dan Pasal 96 dilakukan oleh korporasi, tuntutan dan sanksi pidananya dijatuhkan terhadap pengurusnya dan pidana dendanya ditambah $1 / 3$ (sepertiga) dari pidana yang dijatuhkan.'

Berdasarkan ketentuan diatas, apabila tindak pidana perikanan dilakukan oleh badan hukum/korporasi maka penuntutannnya dibebankan kepada pengurusnya. Selain itu, pembebanan sanksi pidana dibebankan pula pada pengurus dari badan hukum/korporasi yang bersangkutan. Diketahui, ajaran konvensional pertanggungjawaban pidana korporasi sebagaimana tercantum pada Pasal 59 KUHP masih diterapkan dalam UU No. 31 Tahun 2004 jo. UU No. 45 tahun 2009 Tentang Perikanan.

\section{Pengaturan Tindak Pidana Perikanan Di Filipina}

a. Bentuk Tindak Pidana

Sistem hukum Filipina merupakan gabungan atau perpaduan dari tradisi Common law ${ }^{14}$ dan Civil Law. Perpaduan ini terlihat dari pembagian hukum materillnya yang sebagian besar dipengaruhi oleh hukum Spanyol. Sedangkan untuk pengaturan hukum formilnya terutama dalam hal acara peradilan dan pembuktian berasal dari Amerika Serikat. Sebagai wujud dari pengaruh hukum Spanyol, Filipina menganut sistem inkuisitorial yaitu hakim sangat berperan aktif dalam menggali setiap perkara atau kasus. Namun setelah masuknya Amerika Serikat, hakim lebih pasif dan bergantung dari pembuktian dari masing-masing pihak yang berperkara. Seperti halnya Indonesia, tindak pidana perikanan di Filipina berpotensi untuk terjadi. Tindak pidana di bidang perikanan yang tergolong berat di Filipina berupa perburuan dan penyelundupan. Perburuan berupa penangkapan ilegal, penjualan dan distribusi produk perikanan bernilai tinggi dan spesies tertentu.

Untuk mengantisipasi dan mengurangi berkembangnya tindak pidana di bidang perikanan pemerintah Filipina membuat ketentuan perundang-undangan di bidang perikanan. Untuk sektor perikanan, Filipina memberlakukan Republic Act No. 8550 atau lebih dikenal dengan nama The Philippine Fisheries Code of 1998. Terdapat beberapa bentuk tindak pidana perikanan yang diatur dalam The Philippine Fisheries Code of 1998. Ketentuan pidana perikanan diatur dalam Chapter VI Prohibitions and Penalties, total terdiri atas 10 (sepuluh) bentuk tindak pidana. Ke-10 (lima) tindak pidana tersebut terdiri atas 10 golongan tindak pidana perikanan. Adapun ke-

14 Arief, B. N. (2011). Perbandingan Hukum Pidana, Jakarta : Rajawali Pers., h. 17. Lihat pula dalam Wijayanta, T \& Firmansyah, H. (2011). Perbedaan Pendapat Dalam Putusan Pengadilan. Yogyakarta : Pustaka Yustisia., h. 76. Berdasarkan perkembangan terakhir diketahui produk perundangundangan tertulis di negara common law saat ini juga mulai digunakan meskipun para lawyer common law masih sulit beradaptasi dengan produk hukum legislatif, hal ini sebagaimana dikemukakan oleh Rene David \& John E. C. Brierley. (1985). Major legal Systems In The World Today An Introduction to the Comparative Study of Law. London, Steven \& Sons, dalam Santoso, T. (2007). Perbandingan Hukum Pidana, Depok: Program Pascasarjana Universitas Indonesia., h. 392. Intisari sub-bab Legislation disadur sendiri oleh penulis. 
10 golongan tindak pidana perikanan tersebut, antara lain disajikan dalam tabel berikut dibawah ini :

Tabel. 2

Golongan Tindak Pidana Perikanan Di Filipina

\begin{tabular}{|c|c|}
\hline Golongan Tindak Pidana & Pasal \\
\hline $\begin{array}{l}\text { Penangkapan ikan } \\
\text { menggunakan peledak, racun } \\
\text { dan lain-lain sebagainya }\end{array}$ & $\begin{array}{l}\text { 1) Kepemilikan bahan peledak, } \\
\text { berbahaya atau beracun at } \\
\text { penangkapan ikan elektronik ilegal } \\
\text { (Section } 88 \text { point 2); } \\
\text { 2) Penggunaan bahan peledak, bahan } \\
\text { berbahaya atau beracun atau } \\
\text { penangkapan ikan elektronik ilegal } \\
\text { yang mengakibatkan cederanya atau } \\
\text { hilangnya nyawa (Section } 88 \text { point 3) } \\
\text { 3) Menyepakati, menjual, atau dengan } \\
\text { cara apa pun membuang, } \\
\text { untuk/sebagai hewan peliharaan atas } \\
\text { spesies yang ditangkap / dikumpulkan } \\
\text { secara ilegal (Section } 88 \text { point 3) } \\
\text { 4) Penggunaan lampu sorot secara illegal } \\
\text { (Section 93) }\end{array}$ \\
\hline $\begin{array}{l}\text { Penggunaan Jaring } \\
\text { Penangkap Ikan Tidak Sesuai } \\
\text { Ketentuan }\end{array}$ & $\begin{array}{l}\text { 1) Termasuk melanggar hukum dalam } \\
\text { penggunaan jaring dengan jaring yang } \\
\text { lebih kecil dari yang diatur (Section } \\
\text { 89) } \\
\text { 2) Penangkapan di perairan kota dan di } \\
\text { semua teluk serta wilayah manajemen } \\
\text { perikanan lainnya dengan } \\
\text { menggunakan peralatan tangkap aktif } \\
\text { atau active fishing gears (Section 90) }\end{array}$ \\
\hline Konversi Hutan Mangrove & $\begin{array}{l}\text { 1) Siapa-pun dilarang untuk mengubah } \\
\text { hutan bakau menjadi tambak/empang } \\
\text { atau untuk tujuan lain apa pun (Section } \\
\text { 94). }\end{array}$ \\
\hline $\begin{array}{l}\text { Pelarangan Eksploitasi dan } \\
\text { Explorasi Terumbu Karang }\end{array}$ & $\begin{array}{l}\text { 1) Setiap orang atau perusahaan dilarang } \\
\text { untuk mengumpulkan, memiliki, } \\
\text { menjual atau mengekspor karang } \\
\text { berharga dan semi-biasa, baik mentah } \\
\text { atau dalam bentuk olahan (Section 91). }\end{array}$ \\
\hline Pelarangan $\quad$ Penggunaan & 1) Setiap orang dilarang untuk \\
\hline $\begin{array}{lrr}\text { Metode } & \text { Muro-Ami } & \text { atau } \\
\text { Peralatan } & \text { Lainnya } & \text { Yang } \\
\text { Bersifat } & \text { Merusak } & \text { Terumbu } \\
\text { Karang } & & \end{array}$ & $\begin{array}{l}\text { menggunakan Muro-Ami atau } \\
\text { peralatan lainnya yang bersifat } \\
\text { menghancurkan terumbu karang, } \\
\text { padang lamun dan habitat biota laut } \\
\text { lain (Section 92). }\end{array}$ \\
\hline $\begin{array}{l}\text { Penangkapan ikan diluar } \\
\text { musim tangkap }\end{array}$ & $\begin{array}{l}\text { 1) Setiap orang dilarang melakukan } \\
\text { penangkapan ikan diluar musim } \\
\text { tangkap (Section 95) }\end{array}$ \\
\hline
\end{tabular}




\begin{tabular}{|l|l|l|}
\hline $\begin{array}{l}\text { Pelarangan tangkap di } \\
\text { kawasan tertentu }\end{array}$ & $\begin{array}{l}\text { Setiap orang dilarang melakukan } \\
\text { penangkapan ikan di tempat cadangan } \\
\text { perikanan, konservasi dan cagar alam } \\
\text { (Section 96) }\end{array}$ \\
2) $\begin{array}{l}\text { Pelarangan setiap jalur migrasi padat } \\
\text { spesies anadrom, katadrom, dan } \\
\text { migrasi lainnya, di daerah termasuk, } \\
\text { tetapi tidak terbatas pada muara sungai } \\
\text { dan muara dalam jarak tertentu } \\
\text { (Section 105). }\end{array}$ \\
\hline $\begin{array}{l}\text { Penangkapan spesies langka, } \\
\text { terancam atau hampir punah }\end{array}$ & $\begin{array}{l}\text { Mengambil atau mengambil spesies } \\
\text { langka, terancam atau hampir punah } \\
\text { (Section 97) }\end{array}$ \\
\hline $\begin{array}{l}\text { Penangkapan Sabalo atau } \\
\text { Indukan }\end{array}$ & 1) $\begin{array}{l}\text { Menangkap atau mengumpulkan } \\
\text { indukan (Section 98) } \\
\text { Mengekspor indukan (Section 99) } \\
\text { Mengimpor atau mengekspor } \\
\text { perikanan atau spesies perikanan } \\
\text { (Section 100) }\end{array}$ \\
\hline Pencemaran lingkungan & 1) \begin{tabular}{l} 
Mencemari perairan (Section 102) \\
\hline
\end{tabular} \\
\hline
\end{tabular}

The Philippine Fisheries Code of 1998 menentukan beberapa perbuatan yang dilarang karena berpotensi menimbulkan kerugian dibidang perikanan. Larangan untuk menggunakan bahan kimia, peledak dan elektronik dalam penangkapan ikan dan larangan untuk melakukan penangkapan terhadap semua jenis ikan. The Philippine Fisheries Code of 1998 juga membebankan pidana bagi setiap orang yang melakukan penangkapan terhadap spesies ikan yang langka dan terancam punah. Larangan untuk menangkap ikan di luar musim tangkap telah diancam pidana menurut undang-undang ini.

\section{b. Sanksi Pidana}

Sanksi pidana dalam undang-undang perikanan Filipina terdiri atas 2 jenis, yaitu pidana penjara (imprisonment) dan denda (fine). Pidana penjara dari jangka waktu minimal 6 (enam) bulan hingga maksimal sampai 20 (duapuluh) tahun, begitupun dengan pidana denda bervariasi antara 10.000 (sepuluh ribu) peso sampai 120.000 (seratus dua puluh ribu) peso. Perumusan sanksi pidana menurut undang-undang perikanan Filipina adalah sebagian besar berbentuk alternatif-kumulatif. Oleh karena dirumuskan secara alternatif-kumulatif, sanksi pidana penjara maupun denda dapat dijatuhkan bersamaan ataupun dapat pula dijatuhkan salah satunya saja.

c. Pertanggungjawaban Pidana

Asas "tiada pidana tanpa kesalahan" juga dianut dalam ketentuan U-undangundang perikanan Filipina. Sebagian besar tindak pidana perikanan, setelah membuktikan unsur actus reus, unsur kesalahan pelaku tindak pidana harus dibuktikan, apakah dalam bentuk unlawfully, knowingly, attempts, uses (kesengajaan) atau fails, neglect (kelalaian). The Philippine Fisheries Code of 1998 tidak menganut konsep pertanggungjawaban pidana mutlak atau strict liability.

Pertanggungjawaban pidana korporasi sebagai subjek hukum dalam tindak pidana perikanan juga diatur dalam The Philippine Fisheries Code of 1998. Section 
90 The Philippine Fisheries Code of 1998 menentukan : "If the owner/operator is a corporation, the penalty shall be imposed on the chief executive officer of the Corporation"

Apabila selama proses pemeriksaan badan hukum terlibat dalam pelanggaran undang-undang ini, sehingga perlu untuk menetapkan dasar pemikiran untuk korporasi, adalah dengan menunjukkan bahwa direktur, atau agen badan hukum yang bertindak dalam cakupan wewenang aktual atau nyata orang tersebut memiliki dasar pemikiran tersebut. Kesalahan korporasi ketika melakukan tindak pidana perikanan menurut ketentuan ini dilihat dari pemikiran atau wewenang dari direktur, atau agen badan hukum perusahaan. The Philippine Fisheries Code of 1998 menentukan bahwa kesalahan korporasi dibebankan langsung tehadap pengurus atau manajemen korporasi bersangkutan.

\section{Perbandingan Undang-Undang Perikanan Indonesia dan Filipina}

a. Perbuatan atau aktivitas yang dilarang

Sebagaimana deskripsi undang-undang kedua negara, dapat diketahui jumlah rumusan tindak pidana yang dimuat oleh undang-undang perikanan IndonesiaFilipina. Undang-Undang No. 31 Tahun 2004 jo. Undang-Undang No. 45 Tahun 2009 berjumlah 17 Pasal (tujuhbelas) rumusan tindak pidana. The Philippine Fisheries Code of 1998 sebagai pembanding memiliki 18 (delapan belas) pasal rumusan tindak pidana di bidang perikanan. Perbedaan segi kuantitas jumlah bentuk tindak pidana, antara Indonesia dan Filipina relatif tidak jauh berbeda. Meskipun demikian, terdapat perbuatan-perbuatan yang dilarang diatur sama oleh undang-undang perikanan kedua negara.

Persamaan yang dimiliki oleh Indonesia dan Filipina dalam penegakan hukum pidana bidang perikanan adalah kedua negara memberlakukan undang-undang khusus bidang perikanan. Wujud perundang-undangan yang dimiliki oleh kedua negara adalah perundang-undangan administratif yang memuat sanksi pidana atau yang biasa disebut dengan administrative penal law. ${ }^{15}$ Indonesia dan Filipina kedua-duanya juga belum memiliki undang-undang tindak pidana tersendiri di bidang perikanan.

Perbuatan atau aktivitas illegal yang diatur oleh Indonesia dan Filipina sebagiannya adalah sama. Sebagai perundang-undangan administratif, kriminalisasi beberapa perbuatan atau aktivitas yang terkait larangan penggunaan alat tangkap terlarang adalah wajib bagi kedua negara. Indonesia dan Filipina melarang bagi setiap orang yang melakukan penangkapan ikan dengan menggunakan bahan kimia, obatobatan, bahan peledak, alat listrik (setrum) atau semacamnya. Bagi kedua negara, penggunaan alat/metode penangkapan ikan sebagaimana dijelaskan merusak terumbu karang atau berbagai jenis makanan alami yang merupakan sumber kehidupan dari segala macam jenis ikan. Rehabilitasi berbagai kerusakan tersebut membutuhkan waktu yang lama dan tentunya berbiaya mahal Seperti larangan penggunaan bahan peledak maupun racun atau polutan di Filipina diatur dalam Section 88, sedangkan di Indonesia diatur dalam Pasal 85.

Meskipun demikian, terdapat salah satu ketentuan pidana dalam The Philippine Fisheries Code of 1998 yang sepatutnya pula diatur dalam undang-undang perikanan Indonesia begitupun pula sebaliknya. Bagi Indonesia adalah ketentuan tentang

15 Adji, I. S. (2011). Pergeseran Hukum Pidana, Jakarta : Diadit Media Press., h. 9. 
larangan penangkapan spesies langka dan terancam punah. Ketentuan atau aturan tentang larangan demikian belum diatur dalam undang-undang perikanan Indonesia, baik sebelum atau sesudah perubahan.

Berbeda halnya Filipina yang telah mengatur ketentuan larangan penangkapan spesies langka, terancam atau hampir punah dalam Section 97. Adapun isi rumusan Section 97 adalah sebagai berikut: "It shall be unlawful to sh or take rare, threatened or endangered species". Berdasarkan Section 97 diatas bentuk menangkap spesies langkah atau bahkan terancam punah ditetapkan sebagai pelanggaran. Aturan ini bertujuan untuk mencegah hilangnya spesies-spesies tertentu. Tanpa adanya ketentuan ini, maka para pelaku akan bebas menangkap spesies dimaksud dan memperdagangkannya secara ilegal di pasar gelap. Untuk Indonesia ketentuan ini diperlukan untuk memberikan perlindungan terhadap spesies tertentu.

Begitupun pula Filipina sebagaimana diatur The Philippine Fisheries Code of 1998 juga harus ditambahkan ketentuan pidana tentang perizinan. Meskipun perumusan pidana tentang perizinan sudah diatur dalam Fisheries Act 1985 No. 137, berbeda dengan undang-undang perikanan Indonesia yang lebih banyak merumuskan ketentuan terkait hal tersebut. Ketentuan The Philippine Fisheries Code of 1998 harus dirumuskan pidana terkait perizinan, seperti pemalsuan surat-surat izin.

b. Sanksi Pidana

Perumusan ancaman pidana dalam Undang-Undang No. 31 Tahun 2004 jo. Undang-Undang No. 45 Tahun 2009 Tentang Perikanan dan The Philippine Fisheries Code of 1998 memiliki perbedaan. Undang-undang perikanan Indonesia menganut perumusan kumulatif, yaitu menjatuhkan pidana penjara dan denda bersamaan. Ketentuan Undang-Undang Perikanan Indonesia menentukan Pidana penjara maksimal 7 (tujuh) tahun dan denda maksimal Rp 20.000.000.00 (dua puluh milliar rupiah). Undang-undang perikanan Filipina menganut perumusan kumulatifalternatif, yaitu menjatuhkan pidana penjara dan denda secara bersamaan atau salah satu-nya saja. Ketentuan undang-undang perikanan Filipina menentukan pidana penjara maksimal 20 (dua puluh) tahun dan denda maksimal 10.000 (sepuluh ribu) Peso s/d 120.000 (seratus dua puluh ribu) Peso.

Perumusan ancaman pidana undang-undang perikanan Indonesia lebih berat dibandingkan Filipina. Perumusan ancaman pidana undang-undang perikanan Indonesia ditentukan bahwa pidana penjara dan pidana denda harus dijatuhkan bersamaan berbeda halnya dengan undang-undang perikanan Filipina hakim dapat menjatuhkan salah satunya saja, pidana penjara atau denda atau kedua-duanya (kumulatif-alternatif).

Pidana penjara maksimal tergolong berat di Filipina. Pidana penjara dalam undang-undang perikanan Indonesia maksimal 7 (tujuh) tahun. Pidana penjara dalam undang-undang perikanan Filipina maksimal 20 (dua puluh) tahun penjara. Undangundang perikanan Indonesia membebankan pidana denda sebesar Rp. 20.000.000.000.00 (dua puluh milliar) Rupiah sedangkan Filipina membebankan pidana denda sebesar 10.000 (sepuluh ribu) Peso s/d 120.000 (seratus dua puluh ribu) Peso.

Hal yang menarik lainnya adalah Undang-Undang No. 31 Tahun 2004 jo. Undang-Undang No. 45 Tahun 2009 mengatur pula sanksi pidana bagi nelayan kecil. Khusus untuk nelayan kecil/pembudidaya ikan kecil perumusan ancaman pidana-nya 
bersifat alternatif dan tunggal. Perumusan ancaman pidana alternatif bagi nelayan kecil sebagaimana ditegaskan dalam Pasal 100B.

"Dalam hal tindak pidana sebagaimana dimaksud dalam Pasal 8, Pasal 9, Pasal 12, Pasal 14 ayat (4), Pasal 16 ayat (1), Pasal 20 ayat (3), Pasal 21, Pasal 23 ayat (1), Pasal 26 ayat (1), Pasal 27 ayat (1), Pasal 27 ayat (3), Pasal 28 ayat (1), Pasal 28 ayat (3), Pasal 35 ayat (1), Pasal 36 ayat (1), Pasal 38, Pasal 42 ayat (3), atau Pasal 55 ayat (1) yang dilakukan oleh nelayan kecil dan/atau pembudi daya-ikan kecil dipidana dengan pidana penjara paling lama 1 (satu) tahun atau denda paling banyak Rp. 250.000.000,00 (dua ratus lima puluh juta rupiah)."

Sedangkan perumusan ancaman pidana tunggal diatur dalam Pasal 100C yang berbunyi :

"Dalam hal tindak pidana sebagaimana dimaksud dalam Pasal 7 ayat (2) dilakukan oleh nelayan kecil dan/atau pembudi daya-ikan kecil dipidana dengan pidana denda paling banyak Rp.100.000.000,00 (seratus juta rupiah).”

Berdasarkan Pasal 100B diketahui bahwa apabila nelayan kecil melakukan tindak pidana perikanan sebagaimana telah ditentukan, maka nelayan kecil dapat dibebankan sanksi pidana penjara paling lama 1 (satu) tahun atau denda sebesar Rp. 250.000.000.00. Jika nelayan kecil melakukan tindak pidana perikanan sebagaimana dirumuskan dalam Pasal 100C, sanksi pidana yang dibebankan adalah pidana denda sebesar Rp. 100.000.000.00. Sanksi pidana dalam Pasal 100B dan C lebih ringan dibandingkan ketentuan lainnya karena yang menjadi subjek pelaku tindak pidana adalah nelayan kecil. Selain itu, motif untuk melakukan tindak pidana perikanan sekadar untuk memenuhi kebutuhan ekonomi sehari-hari atau ketidaktahuan mengenai regulasi di bidang perikanan. The Philippine Fisheries Code of 1998 Filipina melalui beberapa ketentuannya tidak mengatur tindak pidana perikanan yang dilakukan oleh nelayan kecil atau pembudidaya ikan kecil.

c. Pertanggungjawaban Pidana

Sistem pertanggungjawaban pidana yang dianut oleh undang-undang perikanan Indonesia dan Filipina adalah sama. Unsur-unsur pertanggungjawaban pidana seperti, kesalahan pembuat berupa kesengajaan maupun kelalaian dinyatakan secara tegas di dalam ketentuan pidana undang-undang perikanan kedua negara. Unsur-unsur kesalahan kesengajaan maupun kelalaian dicantumkan secara tegas sebagai unsur tindak pidana dalam banyak pasal di undang-undang perikanan Indonesia. Sebagai contoh dalam Pasal 85 yang berbunyi :

"Setiap orang yang dengan sengaja di wilayah pengelolaan perikanan Republik Indonesia memiliki, menguasai, membawa, dan/atau menggunakan alat penangkapan ikan dan/atau alat bantu penangkapan ikan yang berada di kapal penangkapan yang tidak sesuai dengan ukuran yang ditetapkan, alat penangkapan ikan yang tidak sesuai dengan persyaratan, atau standar yang ditetapkan untuk tipe alat tertentu dan/atau alat penangkapan ikan yang dilarang."

Berdasarkan Pasal 85 diatas bahwa larangan penggunaan alat penangkapan ikan yang tidak sesuai ukuran yang ditetapkan atau tidak sesuai standar menyatakan secara tegas unsur kesalahan. Unsur kesalahan berupa kesengajaan menggunakan alat penangkapan ikan tidak sesuai ukuran atau standar termasuk pula dalam bagian inti tindak pidana/delik Pasal 85. Oleh karena itu, penggunaan alat penangkapan ikan tidak sesuai ukuran maupun standar dengan unsur kesengajaan harus dapat 
dibuktikan. Apabila penggunaan alat penangkapan ikan tersebut digunakan tidak dengan unsur kesengajaan, melainkan kelalaian misalnya, maka pelaku tidak dapat dipertanggungjawabkan dengan menggunakan Pasal 85 ini.

Sama halnya dengan undang-undang perikanan Filipina juga merumuskan unsur kesalahan berupa kesengajaan maupun kelalaian sebagai bagian inti dalam beberapa pasal tindak pidana bidang perikanan. Salah satu ketentuan tersebut adalah Section 88 (1) :

"It shall be unlawful for any person to catch, take or gather or cause to be caught, taken or gathered, sh or any shery species in Philippine waters with the use of electricity, explosives, noxious or poisonous substance such as sodium cyanide in the Philippine shery areas, which will kill, stupefy, disable or render unconscious sh or shery species: Provided, That the Department, subject to such safeguards and conditions deemed necessary and endorsement from the concerned LGUs, may allow, for research, educational or scientic purposes only, the use of electricity, poisonous or noxious substances to catch, take or gather sh or shery species: Provided, further, That the use of poisonous or noxious substances to eradicate predators in shponds in accordance with accepted scientic practices and without causing adverse environmental impact in neighboring waters and grounds shall not be construed as illegal fishing”.

Section 88 (1) menegaskan larangan penggunaan peledak, racun maupun setrum guna mendapatkan keuntungan dalam usaha bidang perikanan dengan disertai unsur kesalahan berupa kesengajaan atau 'unlawful'. Selain harus membuktikan memang benar ada penggunaan metode penangkapan ikan yang dilarang, mutlak pula dibuktikan bahwa perbuatan tersebut dilakukan dengan adanya unsur kesengajaan dari pelaku tindak pidana.

Persamaan terdapat pula tentang ajaran pertanggungjawaban pidana antara undang-undang perikanan Indonesia maupun Filipina. Konsep pertanggungjawaban pidana kedua negara masih bersifat konvensional dengan mengutamakan ajaran "tiada pidana tanpa kesalahan". Undang-undang perikanan Indonesia dan Filipina tidak mengenal konsep pertanggungjawaban mutlak atau strict liability ${ }^{16}$.

Konsep strict liability perlu untuk diterapkan kedalam undang-undang perikanan Indonesia dan Filipina. Konsep strict liability penting untuk mengimbangi pesatnya perkembangan keilmuwan dan teknologi dari suatu kegiatan (industri), khususnya yang bergerak dalam usaha pengelolaan sumber daya perikanan. Konsep strict liability berfungsi sebagai back up dari kekurangan konsep fault based liability sehingga menghapus potensi timbulnya pencemaran atau perusakan sumber daya perikanan tanpa dapat dikenakan pertanggungjawaban pidana.

Pandangan tersebut sesuai dengan pandangan James E. Krier ${ }^{17}$ yang berpendapat bahwa doktrin tanggungjawab mutlak dapat merupakan bantuan yang sangat besar dalam peradilan mengenai kasus-kasus lingkungan, karena banyak kegiatan-kegiatan yang menurut pengalaman menimbulkan kerugian terhadap

16 Ungkapan "strict liability" dikemukakan oleh W.H. Winfield pada tahun 1926 dalam sebuah artikel yang berjudul "The Myth of Absolute Liability" lihat dalam Muladi \& Priyatno, D. (2007). Pertanggungjawaban Pidana Korporasi. Jakarta : Kencana., h. 107.

17 Krier, J. E. dalam Hardjasoemantri, K. (1993). Hukum Tata Lingkungan Edisi Kelima Cetakan Kesepuluh. Yogyakarta : Gadjah Mada University Press., h. 358-359. 
lingkungan merupakan tindakan-tindakan yang berbahaya, untuk mana dapat diberlakukan ketentuan tanggungjawab tanpa kesalahan.

Untuk hukum pembuktian, James E. Krier ${ }^{18}$ lebih lanjut mengemukakan bahwa salah satu kriteria tradisional yang menentukan pembagian beban pembuktian seyogyanya diberikan kepada pihak yang mempunyai kemampuan terbesar untuk memberikan bukti tentang sesuatu hal. Dalam hubungan dengan kerusakan atau pencemaran lingkungan oleh kegiatan industri, maka terang si perusak dan atau pencemar itu yang mempunyai kemampuan lebih besar untuk memberikan pembuktian. Berdasarkan prinsip pencemar membayar dan asas tanggungjawab mutlak ini, dikembangkanlah di dalam ilmu hukum prosedur tentang pembuktian disebut "shifting (oralleviating) of burden of proofs".

Secara umum konsep pertanggungjawaban mutlak atau strict liability sudah dirumuskan dalam ketentuan perundang-undangan Indonesia. Perundanganundangan tersebut adalah Undang- Undang No. 32 Tahun 2009 Tentang Pengelolaan Lingkungan Hidup. Undang-Undang No. 32 Tahun 2009 melalui Pasal 88 berbunyi :

"Setiap orang yang tindakannya, usahanya, dan/atau kegiatannya menggunakan B3, menghasilkan dan/atau mengelola limbah B3, dan/atau yang menimbulkan ancaman serius terhadap lingkungan hidup bertanggungjawab mutlak atas kerugian yang terjadi tanpa perlu pembuktian unsur kesalahan."

Meskipun demikian, cakupan Pasal 88 undang-undang lingkungan hidup tidak dapat diberlakukan dalam kasus-kasus tindak pidana perikanan. Konsep pertanggungjawaban pidana dalam tindak pidana perikanan di Indonesia hanya tunduk berdasarkan ketentuan Undang-Undang No. 31 Tahun 2004 jo. UndangUndang No. 45 Tahun 2009 Tentang Perikanan. Untuk itu, konsep strict liability harus pula dimasukkan dalam regulasi bidang perikanan bukan hanya dalam ketentuan pengelolaan lingkungan hidup.

Pertanggungjawaban pidana korporasi dalam tindak pidana perikanan diatur juga oleh undang-undang perikanan Indonesia dan Filipina. Undang-undang perikanan kedua negara telah mengatur pertanggungjawaban pidana korporasi dibidang perikanan. Untuk sistem pertanggungjawaban pidana korporasi sendiri terdapat beberapa macam bentuk sistem yang dikenal dalam hukum pidana. Sutan Remy Sjahdeini menggolongkan empat sistem pertanggungjawaban pidana korporasi yaitu $^{19}$ :

1) Pengurus korporasi sebagai pelaku tindak pidana, sehingga, oleh karena pengurusnyalah yang harus memikul pertanggungjawaban pidana;

2) Korporasi sebagai pelaku tindak pidana, tetapi pengurus yang harus memikul pertanggungjawaban pidana;

3) Korporasi sebagai pelaku tindak pidana dan korporasi itu sendiri yang harus memikul pertanggungjawaban pidana; pengurus dan korporasi keduanya sebagai pelaku tindak pidana, dan keduanya pula yang harus memikul pertanggungjawaban pidana;

4) Pengurus dan korporasi keduanya sebagai pelaku tindak pidana, dan keduanya pula yang harus memikul pertanggungjawaban pidana.

Berdasarkan pembagian sistem diatas, Indonesia melalui Undang-Undang No. 31 Tahun 2004 jo. Undang-Undang No. 45 Tahun 2009 menganut sistem yang kedua.

\footnotetext{
${ }^{18}$ Ibid, h. 359

19 Sutan Remy Sjahdeini., Op.Cit., h. 59.
} 
Undang-undang perikanan Indonesia menggunakan sistem pertanggungjawaban yang menempatkan korporasi sebagai pelaku tindak pidana perikanan, tetapi pengurus yang harus memikul pertanggungjawaban pidana. Undang-undang perikanan Indonesia masih menganut pembebanan pertanggungjawaban pidana konvensional dimana tentunya tidak lagi mengikuti perkembangan hukum pidana dan perkembangan dunia bisnis perikanan.

The Philippine Fisheries Code of 1998 sama halnya Indonesia dimana sistem pembebanan yang dianut adalah korporasi sebagai pelaku tindak pidana perikanan dan pengurus itu sendiri yang harus memikul pertanggungjawaban pidana sebagaimana ditegaskan dalam Section 90. Sebagai respon terhadap perkembangan ilmu maupun bisnis perikanan, kedepannya Undang-undang perikanan kedua negara harus segera menerapkan sistem pertanggungjawaban korporasi secara penuh dimana korporasi maupun pengurusnya dapat dibebankan pidana secara bersama-sama.

Perkembangan sistem pertanggungjawaban pidana korporasi telah diterapkan secara penuh dalam beberapa kasus illegal fishing. Adapun kasus tindak pidana perikanan yang melibatkan korporasi salah satunya pernah terjadi di Selandia Baru adalah sebagai berikut :

1) Western Bay Seafoods Limited ditetapkan bersalah atas tuduhan membawa ikan tidak tercatat atau dilaporkan sebagaimana yang disyaratkan dalam undangundang perikanan di Pengadilan Negeri Tauranga. Pengadilan menjatuhkan pidana denda sebesar \$22.500 kepada Western Bay Seafoods Limited. Dipersidangan Western Bay Seafoods terbukti memasarkan 270 potong ikan tidak layak konsumsi dalam dua truk chiller, dan beberapa hasil tangkapan yang tidak tercatat diantarkan ke Pasar Ikan Segar, Bay Seafoods 'di Dive Cr. ${ }^{20}$

2) Perusahaan perikanan Karaka dan direktur Martin William Nepia keduanya dituntut dengan dakwaan bersama-sama membuat informasi/pernyataan palsu yang bertentangan dengan Pasal 230 undang-undang perikanan 1996. Direktur Mr Nepia didenda \$18.000 ditambah biaya pengadilan dan Perusahaan Perikanan Karaka didenda \$ 12.000 untuk pelanggaran yang sama. Perusahaan perikanan Karaka dan Direktur Nepia dengan menggunakan informasi palsu memperoleh keuntungan sebanyak 64 ton yang bernilai jual sebesar $\$ 850.000 .^{21}$

Pemidanaan bagi korporasi bidang perikanan di Selandia Baru diharapkan menjadi cerminan bagi Indonesia dan Filipina. Pemidanaan tersebut berlangsung efektif karena perundang-undangan telah menempatkan korporasi sebagai pelaku tindak pidana dan dapat dipertanggungjawabkan. Berbeda halnya dengan Indonesia dan Filipina, meskipun mengakomodasi korporasi sebagai pelaku tindak pidana, namun pertanggungjawaban dibebankan kepada pengurus yang tentunya tidak sesuai lagi dengan tingkat kejahatan bidang perikanan, terutama penangkapan ikan illegal yang dilakukan oleh korporasi atau perusahaan asing.

20 Sandra Conchie (Ed), \$22.500 Fine For illegal Market's Fish, $<$ http://www.nzherald.co.nz/nz/news/article.cfm?c_id=1\&objectid=10833319>. (Diakses pada tanggal 3 Mei 2019).

${ }^{21} \mathrm{http}$ ://www.fish.govt.nz/ennz/Press/Southland+company+and+director+sentenced+on+fishing+re porting+charges.htm. (Diakses pada tanggal 3 Mei 2019). 


\section{P E N U T U P}

Indonesia dan Filipina memberlakukan undang-undang khusus sebagai bagian dari upaya penegakan hukum pidana bidang perikanan. Indonesia memberlakukan UndangUndang No. 31 Tahun 2004 jo. Undang-Undang No. 45 Tahun 2009 Tentang Perikanan dan Filipina memberlakukan The Philippine Fisheries Code of 1998. Meskipun demikian, kedua negara belum memiliki undang-undang tindak pidana khusus bidang perikanan, undang-undang perikanan kedua negara adalah perundangan administratif perikanan yang bersanksi pidana atau dikenal dengan nama administratif penal law. Undangundang perikanan Indonesia dan Filipina mengancam pidana beberapa perbuatan yang terkait dengan perizinan dan metode penangkapan ikan. Undang-undang perikanan Indonesia belum mengatur tentang larangan menangkap spesies langka dan terancam punah. Undang-undang perikanan Filipina belum memiliki sanksi pidana bagi pelanggaran dibidang perizinan, teruatam pemalsuan surat-surat perizinan. Perumusan ancaman pidana baik penjara ataupun denda, undang-undang perikanan Filipina relatif lebih berat dibandingkan Indonesia. Konsep pertanggungjawaban pidana undang-undang perikanan kedua negara masih konvensional. Kesalahan berupa kesengajaan terdapat dalam perumusan ketentuan pasal masing-masing negara. Pertanggungjawaban pidana korporasi oleh kedua negara masih membebankan pertanggungjawaban pidana hanya kepada pengurus korporasi. Undang-undang perikanan kedua negara tidak menganut sistem pertanggungjawaban mutlak.

\section{DAFTAR PUSTAKA}

\section{Buku}

[1] Amiruddin \& Asikin, H. Z. (2008). Pengantar Metode Penelitian Hukum. Jakarta : Rajawali Pers.

[2] Adji, I. S. (2011). Pergeseran Hukum Pidana, Jakarta : Diadit Media Press.

[3] Arief, B. N. (2011). Perbandingan Hukum Pidana, Jakarta : Rajawali Pers..

[4] Bouman, P. J. (1961). Sosiologi Pengertian Dan Masalah. Semarang: Yayasan Kanisius.

[5] Cruz, P. D. (1993). A Modern Approach to Comparative Law. Boston : Kluwer.

[6] Fauzi, A. (2005) Kebijakan Perikanan dan Kelautan. Jakarta: Gramedia Pustaka Utama.

[7] Krier, J. E. dalam Hardjasoemantri, K. (1993). Hukum Tata Lingkungan Edisi Kelima Cetakan Kesepuluh. Yogyakarta : Gadjah Mada University Press.

[8] Muladi \& Priyatno, D. (2007). Pertanggungjawaban Pidana Korporasi. Jakarta : Kencana.

[9] Parthiana, I W. (2003). Hukum Pidana Internasional Dan Ekstradisi. Bandung : Yrama Widya.

[10] Pakes, F. (2010). Comparative Criminal Justice. Cullompton : Willan Publishing.

[11] Soekanto, S. (1986). Pengantar Penelitian Hukum. Jakarta : UI-Press.

[12] Syaukani, I \& Thohari, A. (2004). Dasar-Dasar Politik Hukum, Jakarta : Rajawali Pers.

[13] Surachman, R. M, \& Maringka, J. S. (2015). Peran Jaksa Dalam Sistem Peradilan Pidana Di Kawasan Asia Pasifik. Jakarta : Sinar Grafika.

[14] Surachman, R. M. Dkk. (2015) Eksistensi Kejaksaan Dalam Konstitusi Di berbagai Negara. Jakarta : Sinar Grafika.

[15] Widodo, J dan Suadi. (2006). Pengelolaan Sumber Daya Perikanan Laut. Yogyakarta: Gajah Mada University Press. 
[16] Wijayanta, T \& Firmansyah, H. (2011). Perbedaan Pendapat Dalam Putusan Pengadilan. Yogyakarta : Pustaka Yustisia.

\section{Skripsi, Tesis, Disertasi dan Lain-Lain}

[17] Santoso, T. (2007). Perbandingan Hukum Pidana, Depok: Program Pascasarjana Universitas Indonesia.

\section{Online/World Wide Web}

[18] http://www.fish.govt.nz/ennz/Press/Southland+company+and+director+sentenced+ on+fishing+reporting +charges.htm. (Diakses pada tanggal 3 Mei 2019).

[19] https://psa.gov.ph/fisheries-situationer. (Diakses pada tanggal 3 Mei 2019).

[20] http://www.pulauseribu.co/2011/10/krisis-perikanan-dunia.html. (Diakses pada tanggal 3 Mei 2019)

[21] Sandra Conchie (Ed), \$22.500 Fine For illegal Market's Fish, $<$ http://www.nzherald.co.nz/nz/news/article.cfm?c_id=1\&objectid=10833319>. (Diakses pada tanggal 3 Mei 2019). 